\title{
ANTIMICROBIAL SUSCEPTIBILITY OF EDWARDSIELLA ICTALURI ISOLATED FROM DIFFERENT FISH SPECIES
}

\author{
MAHMOUD MOSTAFA MAHMOUD \\ Department of Animal Medicine, Faculty of Veterinary Medicine, Assiut University, Assiut 71526, Egypt
}

\begin{abstract}
Received at: 31/3/2013

Edwardsiella ictaluri strains isolated from different fish species in different geographic areas (Japan, Indonesia, Vietnam and USA) were screened against 15

Accepted: 29/4/2013 antimicrobial agents. The antimicrobial susceptibility was examined using the Minimum Inhibitory Concentration (MIC) test. Except for only one of the tested strains (DTHN01), the others were found to be susceptible, with high percentages, to most agents active against gram negative bacteria such as aminoglycosides, $\beta$ lactams, quinolones, tetracyclines, and chloramphenicol. Resistance was observed against colistin, sulfisozole, Polymixin B sulfate and Vancomycin.
\end{abstract}

Key words: Antimicrobial susceptibility, Edwardsiella ictaluri, MIC

\section{INTRODUCTION}

Edwardsiella ictaluri is the etiologic agent of an acute septicemic disease of catfish which has been termed "enteric septicemia of catfish" (ESC). It was first isolated in 1976 (Hawke, 1979) and causes economic losses in channel catfish, Ictalurus punctatus, aquaculture. Subsequently, E. ictaluri infection was recorded in many fish species worldwide including catfishes and non-catfishes (Evance et al., 2011; Hassan et al., 2012; Plumb and Hanson, 2011). The prevention and treatment of this disease has become of major importance.

Antibiotics are still the common means of control and are applied usually to the feed mixture either prophylactically or to treat an existing infection. Hawke (1979) was the first to test the antimicrobial susceptibility of $10 \mathrm{E}$. ictaluri isolates. Later, Waltman and Shotts (1986) screened 118 E. ictaluri isolates retrieved in the United States for susceptibility to 37 antimicrobials using the disc sensitivity test. They found that the majority of isolates were susceptible to most agents active against Gram-negative bacteria, but resistance was observed against colistin and sulfonamides in more than $90 \%$ of isolates.

Reger et al. (1993) likewise tested the antimicrobial susceptibility of American E. ictaluri isolates and found full susceptibility to gentamicin, and doxycycline. Thereafter, Stock and Wiedemann (2001) studied the antimicrobial susceptibility of 41 E. ictaluri strains to 71 antibiotics. All these isolates originated from American channel catfish, and hardly any acquired resistance was detected. Recently, Dung et al. (2008) discussed the in vitro susceptibility of 64
Vietnamese isolates and described the acquired resistance developed against some antimicrobial agents. Evaluation of the susceptibility to commonly used antimicrobials will assist in determination of their efficacy and emphasize which agents are effective and can be used in the future.

In the last few years, E. ictaluri isolates were recovered from different fish species including striped catfish, Panagasius hypophthalmus, in Indonesia and Vietnam (Yuasa et al., 2003 and Hassan et al., 2010) and ayu, Plecoglossus altivelis, in Japan (Nagai et al., 2008; Sakai et al., 2008; Hassan et al., 2012). Those isolates were characterized biophysically, biochemically, antigenically and genetically (Hassan et al., 2012; Mahmoud and Nakai, 2011). Yet, they have not been tested for their susceptibility to antimicrobial agents.

The current study was designed to assess the in vitro susceptibility of the used strains to different antimicrobial agents. This is the first report on the antimicrobial susceptibility of the current strains.

\section{MATERIALS and METHODS}

\section{Bacterial strains:}

A total of 12 isolates of E. ictaluri of different origin was collected and studied. Their sources, distributions, and year of isolation are given in Table 1. Isolates were maintained in glycerol broth and kept at $-80^{\circ} \mathrm{C}$.

\section{Antimicrobial agents:}

Fifteen antimicrobial agents were screened for their activity against E. ictaluri. These agents are ampicillin, amoxicillin ( $\beta$ lactams); tetracycline, 
oxytetracycline gentamycin,

(tetracyclines); neomycin,

kanamycin, streptomycin (aminoglycosides); chloramphenicol; nalidixic acid and oxolinic acid (quinolones); sulfisozole; colistin; polymixin B sulfate and vancomycin. They were dissolved in appropriate solvents to make stock solutions and then further diluted in sterile distilled water according to the methods recommended by the Clinical and Laboratory Standards Institute (CLSI M7-A7, 2006).

\section{Susceptibility testing:}

Minimum Inhibitory Concentration (MIC) tests were carried out using microdilution procedure in MuellerHinton broth. Each antimicrobial agent was two-fold serially diluted using 96-well sterile plastic microdilution plates. Final concentrations of 0.1-625 $\mu \mathrm{g} / \mathrm{ml}$ were tested for all antimicrobial agents. Inocula were prepared by suspending bacterial cultures $\left(25^{\circ} \mathrm{C}\right.$, 48 hours) in Mueller-Hinton broth. Approximately $1 \times 10^{5}$ colony forming units (cfu) of the strains were then inoculated on the antibiotic-containing plates and on antibiotic-free control plates, after which plates were incubated at $25^{\circ} \mathrm{C}$ for 48 hours. The MIC was detected as the lowest concentration of the antimicrobial agent with no visible bacterial growth. Each antimicrobial agent was examined trice and the mean MIC values were evaluated for variations using the student $t$ test for multiple comparisons. The interpretation of the MIC results as susceptible, intermediate and resistant was done following the interpretive standards (in $\mu \mathrm{g} / \mathrm{ml}$ ) of Clinical and Laboratory Standards Institute (2007).

\section{RESULTS}

The patterns of antimicrobial susceptibility of the tested E. ictaluri strains $(n=12)$ showed that all strains were susceptible to the used $\beta$ lactam antibiotics (ampicillin and amoxicillin). Also, two of the aminoglycoside antibiotics (kanamycin and gentamycin) exhibited the same pattern with $100 \%$ susceptible strains, while the other two antibiotics displayed less effectiveness where $75 \%$ and $25 \%$ only of the strains were susceptible to neomycin and streptomycin respectively. The susceptibility to tetracyclines (tetracycline and oxytetracycline), quinolones (nalidixic and oxolinic acids), and chloramphinicol were almost same (91.7 \% susceptible strains). On the other hand, sulfisozole, colistin, polymixin B, and vancomycin proved ineffectiveness against E. ictaluri with $100 \%$ resistance. The detailed data are shown in Table 2.

An overview of the MIC values for the different $E$. ictaluri isolates is shown in Table 3. For the pathogen isolated from different fish species, MIC values did not display big difference in between except for DTHN01 strain that was isolated from striped catfish in Vietnam. All strains had high MIC values which were equal to or above $58.6 \mu \mathrm{g} / \mathrm{ml}$ in case of sulfisozole, colistin, polymixin $\mathrm{B}$, and vancomycin.

Table 1: Sources of Edwardsiella ictaluri strains

\begin{tabular}{|c|c|c|c|c|}
\hline \multirow{2}{*}{ Bacterial strains } & \multicolumn{4}{|c|}{ Bacterial sources } \\
\hline & Host fish & Locality & Year & Reference \\
\hline JCM1680 (ATCC33202) & Channel catfish $^{a}$ & USA & $1970 \mathrm{~s}$ & Hawke et al. (1981) \\
\hline JF0384 & Striped catfish $^{b}$ & Indonesia & 2003 & Yuasa et al. (2003) \\
\hline DTHN01 & Striped catfish & Vietnam & 2009 & Hassan et al. (2010) \\
\hline PH0744 & Ayu & Japan & 2007 & Nagai et al. (2008) \\
\hline FPC1095 & $\operatorname{Ayu}^{c}$ & Japan & 2008 & Sakai et al. (2009a) \\
\hline FPC1096 & Ayu & Japan & 2008 & Sakai et al. (2009a) \\
\hline FPC1100 & Ayu & Japan & 2008 & Sakai et al. (2009a) \\
\hline РT0801 & Ayu & Japan & 2008 & Hassan et al. (2012) \\
\hline AH0816 & Ayu & Japan & 2008 & Hassan et al. (2012) \\
\hline AH0901 & Ayu & Japan & 2009 & Hassan et al. (2012) \\
\hline D4 & Ayu & Japan & 2008 & Hassan et al. (2012) \\
\hline Oth29 & Forktail bullhead $^{d}$ & Japan & 2008 & Hassan et al. (2012) \\
\hline $\begin{array}{l}\text { Irus punctatus } \\
\text { glossus altivelis }\end{array}$ & $\begin{array}{l}\text { gasius hypophthalm } \\
\text { obagrus nudiceps }\end{array}$ & & & \\
\hline
\end{tabular}


$\underline{\text { Assiut Vet. Med. J. Vol. } 59 \text { No. } 137 \text { April } 2013}$

Table 2: Patterns of antimicrobial susceptibility of Edwardsiella ictaluri strains

\begin{tabular}{lccc}
\hline \multicolumn{1}{c}{ Antimicrobial agent } & \% Susceptible & \% Intermediate & \% Resistant \\
\hline Ampicillin & 100 & 0 & 0 \\
\hline Amoxicillin & 100 & 0 & 0 \\
\hline Tetracycline & 91.7 & 8.3 & 0 \\
\hline Oxytetracycline & 91.7 & 0 & 8.3 \\
\hline Kanamycin & 100 & 0 & 0 \\
\hline Gentamycin & 100 & 0 & 0 \\
\hline Neomycin & 75 & 16.7 & 8.3 \\
\hline Streptomycin & 25 & 66.7 & 8.3 \\
\hline Chloramphenicol & 91.7 & 0 & 8.3 \\
\hline Nalidixic acid & 91.7 & 0 & 8.3 \\
\hline Oxolinic acid & 91.7 & 0 & 8.3 \\
\hline Sulfisozole & 0 & 0 & 100 \\
\hline Colistin & 0 & 0 & 100 \\
\hline Polymixin B sulfate & 0 & 0 & 100 \\
\hline Vancomycin & 0 & 0 & 100 \\
\hline
\end{tabular}

Table 3: Minimum inhibitory concentration (MIC) values ( $\mu \mathrm{g} / \mathrm{ml} \pm \mathrm{SD}$ ) of Edwardsiella ictaluri strains to 15 antimicrobial agents

\begin{tabular}{|c|c|c|c|c|c|c|c|c|c|c|c|c|}
\hline \multirow{2}{*}{$\begin{array}{c}\text { Antimicrobial } \\
\text { agent }\end{array}$} & \multicolumn{12}{|c|}{ Edwardsiella ictaluri strains } \\
\hline & JCM1680 & JF0384 & DTHN01 & PH0744 & FPC1095 & FPC1096 & FPC1100 & РT0801 & AH0816 & AH0901 & D4 & Oth29 \\
\hline Ampicillin & $1.2 \pm 0.0$ & $1.2 \pm 0.0$ & $1.2 \pm 0.0$ & $0.9 \pm 0.4$ & $1.2 \pm 0.0$ & $1.2 \pm 0.0$ & $0.9 \pm 0.6$ & $1.2 \pm 0.0$ & $0.6 \pm 0.0$ & $1.2 \pm 0.0$ & $0.6 \pm 0.0$ & $0.6 \pm 0.0$ \\
\hline Amoxicillin & $0.1 \pm 0.0$ & $0.2 \pm 0.1$ & $0.1 \pm 0.0$ & $0.6 \pm 0.5$ & $0.1 \pm 0.0$ & $0.4 \pm 0.2$ & $0.1 \pm 0.0$ & $0.1 \pm 0.0$ & $0.5 \pm 0.0$ & $0.1 \pm 0.0$ & $0.2 \pm 0.1$ & $0.2 \pm 0.1$ \\
\hline Tetracycline & $0.3 \pm 0.0$ & $0.3 \pm 0.0$ & $14.6 \pm 6.8^{*}$ & $0.5 \pm 0.2$ & $0.6 \pm 0.0$ & $0.5 \pm 0.2$ & $0.5 \pm 0.2$ & $0.6 \pm 0.0$ & $0.6 \pm 0.0$ & $0.3 \pm 0.0$ & $0.6 \pm 0.0$ & $0.5 \pm 0.0$ \\
\hline Kanamycin & $1.8 \pm 0.8$ & $1.2 \pm 0.0$ & $0.9 \pm 0.4$ & $3.6 \pm 1.7$ & $0.9 \pm 0.4$ & $0.9 \pm 0.6$ & $0.9 \pm 0.6$ & $1.2 \pm 0.0$ & $1.6 \pm 0.6$ & $1.2 \pm 0.0$ & $1.2 \pm 0.0$ & $1.2 \pm 0.0$ \\
\hline Gentamycin & $1.2 \pm 0.0$ & $1.2 \pm 0.0$ & $1.2 \pm 0.0$ & $0.5 \pm 0.2$ & $1.2 \pm 0.0$ & $1.2 \pm 0.0$ & $0.5 \pm 0.2$ & $1.2 \pm 0.0$ & $1.2 \pm 0.0$ & $1.2 \pm 0.0$ & $0.6 \pm 0.0$ & $1.2 \pm 0.0$ \\
\hline Neomycin & $5.9 \pm 4.9$ & $1.8 \pm 0.8$ & $625 \pm 0.0 *$ & $3.6 \pm 1.7$ & $2.4 \pm 0.0$ & $3.6 \pm 1.7$ & $2.4 \pm 0.0$ & $1.5 \pm 0.3$ & $4.8 \pm 0.0$ & $1.5 \pm 1.3$ & $3.6 \pm 1.7$ & $3.6 \pm 1.7$ \\
\hline Streptomycin & $4.8 \pm 0.0$ & $1.5 \pm 1.3$ & $625 \pm 0.0 *$ & $4.8 \pm 0.0$ & $4.8 \pm 0.0$ & $4.8 \pm 0.0$ & $4.8 \pm 0.0$ & $1.5 \pm 1.3$ & $4.8 \pm 0.0$ & $1.5 \pm 1.3$ & $4.8 \pm 0.0$ & $4.8 \pm 0.0$ \\
\hline Nalidixic acid & $0.3 \pm 0.0$ & $0.2 \pm 0.0$ & $234.4 \pm 110.4 *$ & $0.2 \pm 0.0$ & $0.2 \pm 0.2$ & $0.2 \pm 0.2$ & $0.5 \pm 0.2$ & $0.5 \pm 0.2$ & $0.1 \pm 0.0$ & $0.6 \pm 0.0$ & $0.2 \pm 0.0$ & $0.2 \pm 0.0$ \\
\hline Oxolinic acid & $0.1 \pm 0.0$ & $0.04 \pm 0.0$ & $625 \pm 0.0^{*}$ & $2.4 \pm 0.0$ & $1.2 \pm 0.0$ & $3.6 \pm 1.7$ & $0.2 \pm 0.0$ & $0.1 \pm 0.0$ & $2.4 \pm 0.0$ & $0.1 \pm 0.0$ & $2.4 \pm 0.0$ & $2.4 \pm 0.0$ \\
\hline Sulfisozole & $78.1 \pm 0.0$ & $78.1 \pm 0.0$ & $312.5 \pm 0.0$ & $156.3 \pm 81.9$ & $156.3 \pm 0.0$ & $156.3 \pm 0.0$ & $156.3 \pm 0.0$ & $78.1 \pm 0.0$ & $156.3 \pm 0.0$ & $29.3 \pm 13.7$ & $156.3 \pm 0.0$ & $156.3 \pm 0.0$ \\
\hline Colistin & $78.1 \pm 0.0$ & $156.3 \pm 0.0$ & $117.2 \pm 55.2$ & $156.3 \pm 0.0$ & $312.5 \pm 0.0$ & $234.4 \pm 110.4$ & $78.1 \pm 0.0$ & $156.3 \pm 0.0$ & $156.3 \pm 0.0$ & $156.3 \pm 0.0$ & $78.1 \pm 0.0$ & $78.1 \pm 0.0$ \\
\hline $\begin{array}{l}\text { Polymixin B } \\
\text { sulfate }\end{array}$ & $78.1 \pm 0.0$ & $28.5 \pm 55.2$ & $78.1 \pm 0.0$ & $58.6 \pm 27.6$ & $117.2 \pm 55.2$ & $78.1 \pm 0.0$ & $78.1 \pm 0.0$ & $78.1 \pm 0.0$ & $117.2 \pm 55.2$ & $117.2 \pm 55.2$ & $156.3 \pm 0.0$ & $58.6 \pm 27.6$ \\
\hline Vancomycin & $156.3 \pm 0.0$ & $197.8 \pm 162.1$ & $156.3 \pm 0.0$ & $156.3 \pm 0.0$ & $234.4 \pm 110.4$ & $234.4 \pm 110.4$ & $312.5 \pm 0.0$ & $156.3 \pm 0.0$ & $156.3 \pm 0.0$ & $312.5 \pm 0.0$ & $312.5 \pm 0.0$ & $312.5 \pm 0.0$ \\
\hline
\end{tabular}

* Significant difference among strains tested against the same antibiotic $(p<0.05)$

\section{DISCUSSION}

E. ictaluri is currently isolated from many fish species everywhere. It was first recorded in channel catfish in USA (Hawke, 1979), however, later on the infection was reported in different localities and the pathogen was isolated from different fish species including cultured Japanese eel, Anguilla japonica; European sea bass, Dicentrarchus labrax; rainbow trout, Oncorhynchus mykiss; wild rudd, Scardinius erythrophthalmus, and ornamental fishes such as green knife fish, Eigemannia virscens; danio, Danio devario, and rosy barb, Puntius conchonus (reviewed in Evance et al., 2011; Plumb and Hanson, 2011) and recently isolated from in Japan (Nagai et al., 2008; Sakai et al., 2008).

Antimicrobial treatment is still the major control method. Plumb and Schwedler (1982) recommended the use of terramycin mixed with feed at the rate of 
$2.5 \mathrm{~g} / 100 \mathrm{lb}$ of fish per day for 10-14 days. Oxytetracycline and ormetoprim-sulfadimethoxine have both been used with varying success, but some E. ictaluri isolates are resistant. Also, not all isolates from the same case exhibited the same resistance pattern (Taylor and Johnson, 1991). The importance of this finding to choice of medication is not yet known. Some isolates have also been found to be susceptible to kanamycin, streptomycin, neomycin, nitrofurantoin, and/or oxolinic acid in vitro (Waltman and Shotts 1986), but none of these are approved for treating the infection in food fish. In addition, more judicious use of oxytetracycline and ormetoprimsulfadimethoxine has resulted in a significant decline in resistant isolates in Mississippi (Noga, 2010), making them more available for use.

The present study confirmed that tetracycline and oxytetracycline are still effective against E. ictaluri with $91.7 \%$ of the tested isolates being susceptible. Only bacteria isolated from the striped catfish in Vietnam were resistant to both drugs which can be attributed to the acquired resistance from their previous use in prophylaxis or treatment of aquaculture in Vietnam (Dung et al., 2008). The $\beta$ lactam antibiotics (ampicillin and amoxicillin), used in the current work, showed $100 \%$ effectiveness against the pathogen. That correlates well with the results of Waltman and Shotts (1986) who described a low MIC for ampicillin. Also, Dung et al. (2008) stated that none of the isolates used in their study $(n=64)$ displayed acquired resistance against amoxicillin. Of the aminoglycosides tested in the present study, two (kanamycin and gentamycin) proved their efficacy in killing the pathogen completely (100\% susceptibility). Similar results have been mentioned previously (Waltman and Shotts, 1986) who found $0 \%$ resistance and low MIC value $(0.5-4 \mu \mathrm{g} / \mathrm{ml})$ for kanamycin. Reger et al. (1993) reported that all examined strains were susceptible to gentamicin. Also, Dung et al. (2008) described no resistance against kanamycin or gentamycin. However, the present work described the developing of resistant or intermediate resistant strains against either neomycin or streptomycin, and the strain DTHN01 represented the resistant one with high MIC values $(625 \mu \mathrm{g} / \mathrm{ml})$ for both antibiotics. These results come in accordance with data shown by Dung et al. (2008) who found acquired resistance to streptomycin (83\% resistance). Chloramphenicol elicited $91.7 \%$ effectiveness against the used strains, with only one strain being resistant (DTNH01). More or less same results have been recorded in different $E$. ictaluri isolates elsewhere (Stock and Wiedemann, 2001). Oxolinic acid has been used to treat fish diseases and has been shown to be effective with little toxicity (Endo et al., 1973; Rogers and Austin, 1983; Austin et al., 1983). The strains used here exhibited slight resistance against the tested Quinolones (nalidixic and oxolinic acids) with only one resistant strain (DTHN01), i.e. 8.3\% resistance with high MIC values of 234.4 and $625 \mu \mathrm{g} / \mathrm{ml}$ for both agents respectively. In their study, Stock and Wiedemann (2001) found that E. ictaluri isolates were naturally sensitive to quinolones.

On the other hand, all the used strains were resistant to sulfisozole, colistin, polymyxin $\mathrm{B}$, and vancomycin (100\% resistance for all of them) and MICs not less than $58 \mu \mathrm{g} / \mathrm{ml}$. Several literatures described the resistance of $E$. ictaluri isolates against these antimicrobial agents (Dung et al., 2008; Reger et al., 1993; Stock and Wiedemann, 2001; Waltman and Shotts, 1986).

The results of antimicrobial susceptibility of E. ictaluri studied here revealed that the strains exhibited a homogeneous antimicrobial susceptibility pattern either in their susceptibility to many antimicrobial agents or resistance to others. Only the strain DTHN01, isolated from the striped catfish in Vietnam, exceptionally showed resistance to many of the used antimicrobial agents. The reason for its resistance to almost all used antimicrobial agents may be attributed to the use of these agents in the routine aquaculture practice that enabled E. ictaluri to acquire such resistance as mentioned above (Dung et al., 2008).

\section{REFERENCES}

Austin, B.; Rayment, J. and Alderman, D.J. (1983): Control of furunculosis by oxolinic acid. Aquaculture. 31: 101-108.

Clinical and Laboratory Standards Institute (2006): Methods for dilution antimicrobial susceptibility tests for bacteria that grow aerobically; approved standard- $7^{\text {th }}$ ed. CLSI document M7-A7. CLSI, Wayne, PA.

Clinical and Laboratory Standards Institute (2007): Performance standards for antimicrobial susceptibility testing; $16^{\text {th }}$ informational supplement. CLSI document M100-S17. CLSI, Wayne, PA.

Dung, T.T.; Haesebrouck, F.; Tuan, N.A.; Sorgeloos, P.; Baale, M. and Decostere, A. (2008): Antimicrobial susceptibility pattern of Edwardsiella ictaluri isolates from natural outbreaks of bacillary necrosis of Pangasianodon hypophthalmus in Vietnam. Microb. Drug Resist. 14 (4): 311-316.

Endo, T.; Ogishima, K; Hayasaka, H.; Kaneko, S. and Ohshima, S. (1973): Application of oxolinic acid as a chemotherapeutic agent against infectious diseases in fishes. I. Antibacterial activity, chemotherapeutic effects, and pharmacokinetics of oxolinic acid in fishes. Bull. Jpn. Soc. Sci. Fish. 39: 165-171. 
Evance, J.J.; Klesius, P.H.; Plumb, J.A. and Shoemaker, C.A. (2011): Edwardsiella septicaemias. In "Fish diseases and disorders" (ed. by P. K. Woo and D. W. Bruno). CABI, London, pp. 512-569.

Hassan, E.S.; Mahmoud, M.M.; Nguyen, H.D.; Yuasa, K. and Naka, T. (2010): Serological characterization of Edwardsiella ictaluri strains isolated from wild ayu Plecoglossus altivelis. Fish Pathol., 45: 43-46.

Hassan, E.S.; Mahmoud, M.M.; Kawato, Y.; Nagai, T.; Kawaguchi, O.; Iida, Y.; Yuasa, K. and Naka, I.T. (2012): Subclinical Edwardsiella ictaluri infection of Wild Ayu Plecoglossus altivelis. Fish Pathol., 47: 64-73.

Hawke, J.P. (1979): A bacterium associated with disease of pond cultured channel catfish, Ictalurus punctatus. J. Fish. Res. Board Can. 36: 1508-1512.

Hawke, J.P.; McWhorter, A.C.; Steigerwalt, A.G. and Brenner, D.J. (1981): Edwardsiella ictaluri sp. nov., the causative agent of enteric septicemia of catfish. Int. J. Syst. Bacteriol. 31: 396-400.

Mahmoud, M.M. and Nakai, T. (2011): Antigenic and genetic characterization of Edwardsiella ictaluri strains. Egypt. J. Aquat. Biol. \& Fish. 15 (3): 317-326.

Nagai, T; Iwamoto, E.; Sakai, T.; Arima, T.; Tensha, K.; Iida, Y.; Iida, T. and Nakai, T. (2008): Characterization of Edwardsiella ictaluri isolated from wild ayu, Plecoglossus altivelis in Japan. Fish Pathol. 43: 158-163.

Noga, E.J. (2010): Fish diseases (ed. by E.J. Noga). Wiley-Blackwell, Ames, Iowa, pp. 190-192.

Plumb, A. and Schwedler, T.E. (1982): Enteric septicemia of catfish (ESC): A new bacterial problem surfaces. Aquaculture Mag. 8: 26-27.
Plumb, J.A. and Hanson, L.A. (2011): Catfish bacterial diseases. In "Health maintenance and principal microbial diseases of cultured fish" (ed. by J.A. Plumb and L.A. Hanson). WileyBlackwell, Ames, Iowa, pp. 275-313.

Reger, P.J.; Mockler, D.F. and Miller, M.A. (1993): Comparison of antimicrobial susceptibility, beta lactamase production, plasmid analysis and serum bactericidal activity in Edwardsiella tarda, E. ictaluri and $E$. hoshinae. J. Med. Microbiol. 39: 273-281.

Rogers, C.J. and Austin, B. (1983): Oxolinic acid for control of enteric redmouth disease in rainbow trout. Vet. Rec. 112: 83.

Sakai, T.; Kamaishi, T.; Sano, M.; Tensha, K.; Arima, T.; Iida, Y.; Nagai, T.; Nakai, T. and Iida, T. (2008): Outbreaks of Edwardsiella ictaluri infection in ayu, Plecoglossus altivelis in Japanese rivers. Fish Pathol. 43, 152-157.

Sakai, T.; Yuasa, K.; Ozaki, A.; Sano, M.; Okuda, R.; Nakai, T. and Iida, T. (2009a): Genotyping of Edwardsiella ictaluri isolates in Japan using amplified-fragment length polymorphism analysis. Lett. Appl. Microbiol. 49: 443-449.

Stock, I. and Wiedemann, B. (2001): Natural antibiotic susceptibilities of Edwardsiella tarda, E. ictaluri, and E. hoshinae. Antimicrob. Agents Chemother. 45(8): 22452255.

Taylor, P.W. and Johnson, M.R. (1991): Antibiotic resistance in Edwardsiella ictaluri. American Fisheries Society Fish Health Section Newsletter. 19 (2): 3-4.

Waltman, W.D. and Shotts, E.B. (1986): Antimicrobial susceptibility of Edwardsiella ictaluri. J Wild Dis. 22: 173-177.

\section{قابلية بكتيريا الإدواردسيلا إكتالورى المعزولة من أنواع مختلفة من الأسماك لمضادات الميكروبات}

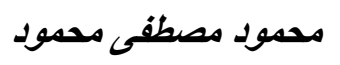

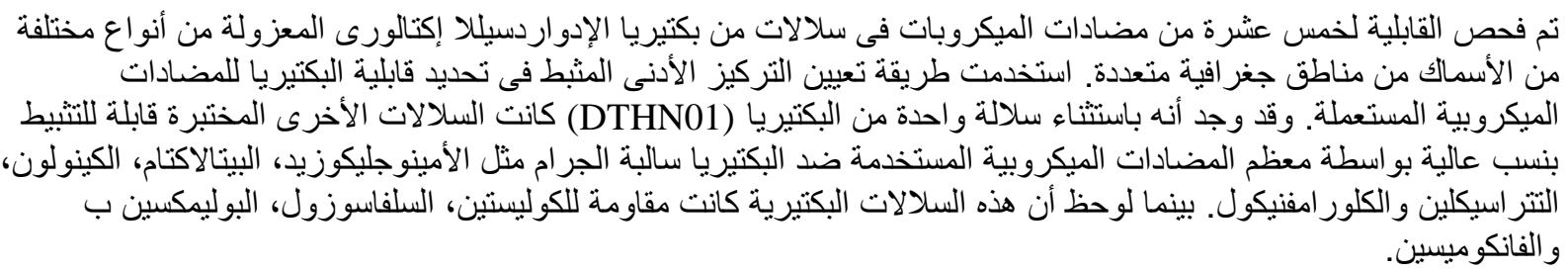

